\title{
Commercializing User Innovations by Vertical Diversification: The User-Manufacturer Innovator
}

Published in Research Policy 45 (2016), 244-259

\author{
Jörn Block ${ }^{1,2,3}$, Joachim Henkel ${ }^{1,4}$, Tim Schweisfurth ${ }^{1}$, Annika Stiegler ${ }^{1}$ \\ ${ }^{1}$ Technische Universität München, TUM School of Management \\ ${ }^{2}$ Universität Trier, Professur für Unternehmensführung \\ ${ }^{3}$ Erasmus Research Institute of Management (ERIM) \\ ${ }^{4}$ Center for Economic Policy Research (CEPR), London
}

\begin{abstract}
This paper explores a pathway to commercializing user innovations hitherto not studied, namely, the vertical diversification of a user firm into an upstream industry supplying capital goods, and subsequent coexistence of user and manufacturing units. Such coexistence creates synergies regarding innovation, marketing, and financials. It enables the manufacturing unit to benefit from user innovations in its new product development, while the user unit profits from improved tools. Yet, selling the firm's own user innovations risks loss of the competitive advantage originating from use of these innovations. We employ case evidence from firms in the fields of foundation engineering, tunnel construction, tea-packaging, and geological surveying to derive a set of five propositions regarding the conditions under which user-manufacturer diversification is attractive and viable in the long run. These conditions relate to innovation, marketing, the organization, and financial aspects. Our study offers three contributions. We show how user entrepreneurship can originate from established corporations rather than from individual user innovators; we carve out factors that favor the move toward and the success of user-manufacturer diversification; and we link user innovation and corporate strategy by showing how user innovation can affect the boundaries of organizations.
\end{abstract}

Keywords: user innovation, commercialization of user innovations, vertical diversification, user entrepreneurship, case study

\section{JEL codes: L25; O31}

Corresponding author: Joachim Henkel (henkel@wi.tum.de, + 4989289 25740) Technische Universität München, TUM School of Management, Arcisstr. 21, D-80333 München, Germany 


\section{Introduction}

When users innovate, they intend to benefit by using their innovations (von Hippel, 1988). However, user innovations can also be valuable to other parties, and in many cases have been shown to have good commercial potential (e.g. Franke and von Hippel, 2003; von Hippel, 2005). Two ways of tapping this potential have been described. The user innovator can either pass its innovation to a manufacturer to integrate it into the latter's new product development (von Hippel et al., 1999), or can commercialize the innovation by becoming a manufacturer herself (Baldwin et al., 2006; Haefliger et al., 2010; Shah and Tripsas, 2007). In the first scenario, the user innovator maintains the functional role of a user; in the second, the user's role switches to that of a manufacturer. However, in both cases, the interaction between manufacturer and user innovator is limited, either because the user innovator remains external to the manufacturer or because the user has abandoned her functional role as a user (von Hippel, 1988).

A long-term and close relationship between the parties is conceivable if a user innovator turned manufacturer retains both roles over the long run, remaining active in the original business as a user, and also selling her user innovations on the market. We refer to this phenomenon as usermanufacturer diversification. The obvious benefits of this configuration are that it enables the usermanufacturer to commercialize a continuous stream of user innovations while simultaneously allowing the in-house user to benefit directly from improved commercial products. On the other hand, selling one's user innovations on the market — and to competitors in particular-risks loss of the competitive advantage that the user unit derives from the innovations. As a result, tensions can arise between the user and manufacturing units that negate the potential synergistic gains.

In this study, we explore two interrelated questions about user-manufacturer diversification: First, what are the characteristics, advantages, and drawbacks of user-manufacturer diversification, 
also in contrast to other pathways of commercializing user innovations? Second, which factors favor or impede the move toward and success of user-manufacturer diversification?

We address these questions using a multiple case study approach to analyze the history, organization, and innovation management of four firms that diversified from their original business using specific equipment (the user business) into a related business manufacturing this equipment (the manufacturing business). Our focal firms are active in the fields of foundation engineering, tunnel construction, tea-packaging, and geological surveying.

Our empirical evidence shows that successful user-manufacturer diversification is possible. Based on detailed case analysis we propose that an organization's tendency to perform such a diversification, and the sustainability thereof, are determined by four groups of factors. In relation to innovation, the favorable factors are a continuous stream of innovations resulting from leadingedge activity by the user unit; in relation to marketing, a good reputation of the focal firm in its original market helps the new manufacturing unit. At an organizational level, conflicts between the user and manufacturing unit might impede the diversification and its success; in relation to finance, diversification helps to cover the investment required for user innovation, and if market cycles are asynchronous, hedges against slumps in demand for the user business. We derive five propositions regarding how these factors favor the move toward and the success of user-manufacturer diversification.

Our study contributes to the literature on user innovation in three ways. First, we show how user entrepreneurship can originate from established firms rather than from individual user innovators (as described by Baldwin et al., 2006; Haefliger et al., 2010; Shah and Tripsas, 2007). We propose a new path to user innovation commercialization, describe this phenomenon in depth, and delineate it from other paths to commercializing user innovations. Second, we reveal the factors 
that favor both the move toward and the success of user-manufacturer diversification. Third, we establish a new link between user innovation and corporate strategy. We show that user innovation can affect the boundaries of the firm and should thus be considered a central strategic issue (Santos and Eisenhardt, 2005; Tushman et al., 2012).

The remainder of the article is organized as follows. Section 2 reviews the relevant literature; Section 3 describes the research method, data sources, and the cases investigated. Drawing on these cases, we develop our propositions in Section 4. Section 5 compares user-manufacturer diversification to alternative pathways to commercialization of user innovation and relates our phenomenon to existing theory. Section 6 concludes and suggests implications for research and management.

\section{Literature review: Commercialization of user innovations}

We first review the literature on how user innovations become commercial products. Known pathways are new product introduction by an existing firm in its core market and the creation of a new firm by the user innovator. Next, we review the literature pertaining to the new pathway we carve out, i.e., diversification into an upstream market based on a firm's own user innovations.

\subsection{New product introduction by existing firms}

We define user need knowledge as knowledge about the needs that current or future users of an existing or potential product experience or will experience in the future. Knowledge about user needs is valuable for firms (von Hippel, 1988), representing problem-related knowledge required for innovation (Alexander, 1964; von Hippel, 1994). Such knowledge is typically located with users external to the firm, and learning from these is important for the success of all the stages in the innovation process. In the invention and development stage, integrating knowledge from 
outside users contributes to the development of successful innovations (Meyers and Athaide, 1991), and innovations that incorporate user knowledge in many cases are of higher importance (Chatterji and Fabrizio, 2012). In the implementation stage, existing firms can learn from users how they use early versions of the product, and obtain information about how products perform in practice (Athaide et al., 1996; Douthwaite and Park, 2001). Close interaction between manufacturers and users is positively related to the implementation of industrial process innovations (Meyers et al., 1999). The integration of users into the innovation process is especially relevant for changing or emerging technologies (Chatterji and Fabrizio, 2013; Douthwaite and Park, 2001; Meyers and Athaide, 1991).

In addition to the exchange of problem-related information with a supplier, user firms often adapt equipment to suit their needs, thereby innovating. Studies show that these firms often share their innovations with upstream equipment manufacturers (de Jong and von Hippel, 2009; Harhoff et al., 2003) and even competitors (Allen, 1983; von Hippel, 1987). In the field of scientific instruments, new devices are often developed by users and then commercialized by an external manufacturer (von Hippel, 1976). Similarly, innovations in the form of off-label uses of drugs are often freely shared (DeMonaco et al., 2006).

Innovating users may also be internal to the firm that eventually commercializes the innovation. There is a growing literature that shows that firm employees often use their firm's products (Harrison and Corley, 2011; Heiskanen et al., 2010; Leonard-Barton, 1992; Schweisfurth and Raasch, 2015; Wadell et al., 2013). These individuals acquire user knowledge by using these products outside the organization and act as boundary spanners, being able to apply this knowledge within organizational boundaries. Firms can draw on this knowledge for ideation and product testing. Research shows that knowledge about internal users' needs contributes to product 
innovation in the fields of outdoors sports (Heiskanen et al., 2010), medical devices (Wadell et al., 2013), and mountaineering (Harrison and Corley, 2011; Schweisfurth and Raasch, 2015). LeonardBarton (1995) shows that internal users are involved in testing prototypes in the fields of razors and barbecue grills.

\subsection{User entrepreneurship and new firm creation}

To explain the innovative activities of users, von Hippel (1986) introduced the concept of lead users, who "anticipate relatively high benefits from obtaining a solution to their needs" and "are at the leading edge of an important market trend" (von Hippel, 2005, p.22). Franke et al. (2006) show that the latter characteristic is associated with the commercial attractiveness of the respective user innovation. While few lead users exploit this attractiveness by becoming manufacturers, which von Hippel (1988) attributes to the difficulties of switching functional roles, some user innovators do turn into manufacturers (Baldwin et al., 2006; Haefliger et al., 2010; Shah and Tripsas, 2007). Shah and Tripsas (2007, p. 124) termed this phenomenon "user entrepreneurship", defined as "the commercialization of a new product and/or service by an individual or group of individuals who are also users of that product and/or service." It is a rather frequent phenomenon-Shah et al. (Shah et al., 2012, p. 2) find that " 46.6 percent of startups founded around an innovative product or service that survive to age five are founded by users." Depending on whether the innovation originated from user needs encountered in the innovator's private or professional life, the authors distinguish between end-user and professional-user entrepreneurs.

Shah and Tripsas (2007) identify the conditions that favor end user entrepreneurship as: the enjoyment the user innovator derives from the use and initial production of the respective innovation; low opportunity costs; and an industry structure characterized by small-scale niche markets. Turbulent markets also increase the likelihood of user entrepreneurship (see Baldwin et 
al. (2006), for a formal model), while the need for complementary assets makes market entry by user entrepreneurs more difficult and therefore unlikely. Haefliger et al. (2010) describe how user entrepreneurs start "under the radar" of incumbent firms, gaining industry and project experience and attracting first customers. In the particular case that Haefliger et al. (2010) study-movies filmed in video games - this is facilitated by the fact that the final product is created using an entirely different process than those originating from incumbent firms.

Professional user entrepreneurship relates to cases where users perceive needs in their professional environment. Lettl and Gemünden (2005) and Lettl et al. (2006) show how physicians working in medical institutions conduct entrepreneurial activities and support the creation of new firms to commercialize radical innovations. Perceiving unmet needs within their work environment, and driven by the lack of resources within their organization, surgeons seek external support. Drawing on the resources provided externally they eventually commercialize their innovations outside their original organization. Winston Smith and Shah (2013) explore this phenomenon in a large scale patent study. They find that established firms tend to include more knowledge from medical startups founded by user entrepreneurs (i.e. physicians who worked as users in medical institutions before) than from non-user startups. Weterings and Koster (2007) study small Dutch software firms and show that professional-user entrepreneurship abounds in this industry. Developers who use a product at work find ways to improve it and start their own ventures. Their former employer may become a customer of the new venture. However, Weterings and Koster (2007) do not find that professional-user entrepreneurs have higher innovative output compared to other entrepreneurs. 


\subsection{Commercializing user innovations through vertical diversification}

The path to commercializing user innovations that we identify in this study has elements common to both of the above types, but also differs from them. Vertical diversification toward an integrated user-manufacturer firm originates as user innovation within a firm, and leads subsequently to the creation of a new business which is part of the original firm.

Vertical diversification has been mainly analyzed from two perspectives. The economics literature focuses on minimizing transaction cost (Williamson, 1973) to explain the location of vertical boundaries. The strategy literature, in contrast, emphasizes the firm's resource endowment (Barney, 2001; Wernerfelt, 1984) and argues that firm boundaries are set to maximize the value of the resource bundle (Santos and Eisenhardt, 2005). Both explanations apply to user-manufacturer diversification: the transaction cost of the transfer of innovation-related information is lower within the firm than to an external manufacturer; and user and manufacturer resources are complementary to each other, i.e., the value of both resource bundles together exceeds the sum of the values of the individual bundles (Adegbesan, 2009; Harrison et al., 1991).

As to the pathway to vertical diversification, the literature (Cantwell et al., 2011) distinguishes between incorporating already existing organizations (Harrigan, 1984) through mergers or acquisitions, and internal development through innovation and entrepreneurial activity (Yip, 1982). Our cases fall into the latter category.

Our study links research on user innovation and firm diversification. It shows that an important form of internal diversification has been neglected so far: a firm may use its capability as a user innovator to expand its business vertically and become a supplier of not inputs but tools and capital goods, to its own and its competitors' businesses. We describe an instance of vertical diversification 
in which the businesses are clearly related, but in an unusual way, that has not been explored so far.

\section{Methods}

\subsection{Sample and Research Design}

\subsubsection{Research method}

In this paper we explore the phenomenon of user-manufacturer diversification. Beyond presenting a description of this phenomenon our aim is to inductively develop new theory in this regard. To achieve these objectives we use an inductive research approach, making use of the richness of qualitative data which is needed for theorizing (Edmondson and McManus, 2007). We follow a case study approach, which provides two main advantages. First, immersion in the richness of detailed case data and use of various sources describing the phenomenon from different perspectives, which provides us with a deep understanding of the commercialization decision and the underlying mechanisms (Eisenhardt and Graebner, 2007). Second, case studies investigate a phenomenon in its context without clearly defined boundaries between context and phenomenon. This allows not only capturing changes of a phenomenon but also provides an understanding why these changes happen and how the underlying mechanisms work (Yin, 2003). We use four cases to build our theory, i.e. we employ a multiple case study approach (Eisenhardt and Graebner, 2007; Siggelkow, 2007). This approach provides greater rigor and generalizability of the findings compared to a single case study (Eisenhardt, 1991).

The case study research is conducted in three phases: (1) sampling, (2) data collection, and (3) data reduction and analysis (Yin, 2003). The phases do not necessarily follow a linear sequence 
and also may be overlapping; the data gathering and data analysis phases revealed aspects that led us to look for additional cases and additional data.

\subsubsection{Sample}

Although a multiple case study approach has advantages regarding theory building, the process of case sampling is more complicated than with a single case study. The choice should be based less on the unique characteristics of a particular case, and guided more by the contribution to theory development among the set of cases. New cases are added to replicate or extend emerging theory and to rule out alternative explanations for outcomes (Eisenhardt and Graebner, 2007; Yin, 2003). This process continues until a stable theory emerges and new information does not change the findings, i.e. until theoretical saturation sets in (Strauss and Corbin, 1990). Accordingly, the selection of case firms was iterative and stepwise. The goal was to select cases in order to maximize what could be learned in relation to our research objectives (Eisenhardt, 1989). We identified four cases where firms had started out as users of a specific product category and then made the transition to manufacturing and selling products in the same category. The first case is Bauer AG, which is a fully vertically integrated, successful, stock market listed user-manufacturer innovator in the specialist foundation construction business. The selection of the other three cases was aimed at both replicating and at the same time getting a deeper and broader understanding of the phenomenon of user-manufacturer diversification in different industry and firm life cycle contexts (Eisenhardt, 1989). Our goal was to understand in detail the unique characteristics, advantages and drawbacks of the phenomenon of user-manufacturer diversification, also in contrast to other pathways of commercializing user innovations. Thus, we followed a theoretical sampling approach in order to either find our emerging theory supported or challenged. To find the cases, we conducted systematic research guided by the emerging findings of the first case. In a first step, we used the 
results of interviews with Bauer AG to construct a list of industries where the phenomenon of usermanufacturer diversification might play a role. We identified the construction, mining, (wind)energy, packaging, chemical, and specialist machinery industries. In a second step, we looked systematically for potential sample firms in these industries using industry registers, membership lists of industry associations, and industry and academic experts. After applying several exclusion criteria (e.g., firm size, data availability, willingness to participate), our sample comprised DMT GmbH \& Co. KG (mining, exploration and geo surveying), Teekanne Group (tea packaging), and Wüwa Bau GmbH \& Co KG (tunnel construction, pipe jacking). Table 1 provides a detailed overview of our four case firms. We now briefly introduce the four cases to describe the course of events from user firm to user-manufacturer innovator, and to locate our findings in the relevant context and make them more comprehensible.

\section{[Insert Table 1 here]}

\subsubsection{Bauer $A G$}

Bauer AG (hereafter Bauer) is active in the specialist foundation engineering business and began developing and producing specialist foundation engineering machines in the 1980s. An important moment in the history of Bauer was the development of the first user innovation, the grouted tieback anchor, in 1958. This "Bauer anchor" was a new superior technique to stabilize the walls of excavation pits and remains the standard approach today. The development of the grouted tieback anchor was the beginning of a period in which Bauer repeatedly developed its own machines and construction techniques. In most cases, the origins of these user innovations were similar to those of the grouted tieback anchor: inadequate material, machines, or techniques for the construction work, and inability of existing manufacturers to provide a solution to Bauer's problems. This forced the firm to develop its own construction machines. 
In 1984, after years of selective sales, Bauer's management decided to adopt a strategy of unrestricted commercialization for its own user innovations, and set up a separate manufacturing unit for this purpose. The manufacturing or machines unit currently accounts for approximately $40 \%$ of the Bauer group's total revenues while employing $30 \%$ of its employees.

\subsubsection{DMT GmbH \& Co. KG}

DMT GmbH \& Co. KG (hereafter DMT) was founded in 1990 as the successor to Westfälische Berggewerkschaftskasse. DMT is now a subsidiary of the TÜV Nord Group (Creditreform, 2010; DMT, 2011) and consists of six units, including an exploration and geological survey unit and a machine and instruments unit which develops machines to conduct exploration services (DMT, 2011). DMT's predecessor's main business in the 1980s was conducting exploration services and underground surveys for the coal mining, oil, and gas industries which required specific machines for the underground work. Since appropriate machines were not available on the market, they decided to develop the exploration machines themselves.

Initially, the goal was to use these machines only internally, but broad commercialization started soon. Today, the instruments unit sells to all customers, and only $10 \%$ to $20 \%$ of its sales go to the company's own geological survey unit. Approximately $60 \%$ of DMT's current service business comes from abroad while $80 \%$ to $90 \%$ of the revenue from the instrument business comes from countries other than Germany.

\subsubsection{Teekanne Group}

The Teekanne Group (hereafter Teekanne) is a family firm founded in 1882 in Dresden. While the firm's roots are in the packaged tea business, Teekanne started to develop and construct its own tea-packing machines in the 1920s (Teekanne, 2007). Teekanne currently comprises several 
subsidiaries among which Teekanne $\mathrm{GmbH}$, the packaged tea business, and Teepack GmbH, the tea-packing machine business, are the most important.

In the 1920s, Teekanne started to sell tea in bags. A machine was needed to fill the tea bags. No such machine existed at the time so Adolf Rambold developed a tea packaging machine for Teekanne. After becoming an employee of Teekanne, he went on to develop the so-called "double chamber bag" and the machines to fill this new type of tea bag. The idea to develop tea-packing machines was geared toward optimizing production.

Due to Mr. Rambold's ability to develop and construct tea-packing machines, Teekanne soon became a lead user which produced its own machines and began to be approached by other firms to purchase machines. In the 1920s and 1930s, Teekanne was selling its machines to tea-packing firms in France, Switzerland, the Netherlands, Italy, and especially, the USA.

Current employment in the firm is about 1,500 of which about 200 employees work in the teapacking machines business. Teekanne generates revenues of about $€ 385$ million.

\subsubsection{Wüwa Bau GmbH \& Co KG}

Wüwa Bau GmbH \& Co KG (hereafter Wüwa) was a family firm founded in 1984, active in the fields of infrastructure tunnel construction, pipe-jacking machines, and equipment manufacturing. Since 2000, Wüwa is a $100 \%$ subsidiary of Max Bögl, the largest family-run construction firm in Germany.

In the 1980s, the construction of infrastructure tunnels through tunnel drilling rather than open construction was new and there was no specialized machinery available. Wüwa soon realized that it would need to develop and manufacture its own machines (Max Bögl, 2003), and became a user innovator. In about 2000, the decision was made to sell these machines to other firms as well as using them internally. Wüwa established its own machine unit and hired construction and sales 
employees for the machine business. Wüwa continues to be active in both areas. Although tunnel construction is the core business, the firm's machine business continues to grow (Max Bögl, 2009). In 2011 , approximately $25 \%$ of the firm's sales were generated by the machine business and $75 \%$ by the construction business. Wüwa currently employs around 70 people and generates revenues of EUR 11.8 million.

\subsection{Data collection}

Our main data source was semi-structured interviews with directors of the firms or units. We used additional data such as shorter, more informal interviews and archival data for data triangulation as suggested by Eisenhardt (1989) and Yin (2003) to increase validity and robustness of our findings (Denzin, 1970). Table 1 provides an overview of the data sources for each case.

The accounts of key informants were the primary information source and the core of our theory building (Gioia et al., 2013). Key informants include current CEOs, former CEOs, and members of company boards. We conducted five semi-structured interviews with representatives of Bauer; two with Thomas Bauer, chief executive officer (CEO) of Bauer and three with Erwin Stötzer, former managing director of Bauer's machines unit (retired in 2008). In Teekanne, we conducted one interview with Stefan Lambertz, a member of Teepack's (Teekanne's manufacturing business unit) managing board, and two interviews with Wilhelm Lohrey, former technical director of Teepack. In Wüwa, we interviewed Hans Loser, a member of the management board of Wüwa, and in DMT we conducted two interviews with Bodo Lehmann, head of DMT's Exploration \& Geosurvey Division. These interviews with key informants lasted for more than 60 minutes, and all but one were recorded and transcribed, resulting in over 200 pages of single spaced text. For the one interview not recorded and the shorter informal interviews, detailed written notes were taken. All the primary interviews were conducted face-to-face by two interviewers. In the first set of 
interviews, we started with the following key questions: What were the reasons for your firm creating user innovations? Why did your firm start to commercialize its user innovations? How would you describe the steps in the process of commercialization of the user innovation? How did financial markets and banks react to the commercialization decision? As the study evolved and the fragments of our theory emerged, we added more detailed questions about the dual role of being a user and a manufacturer in one firm. Table 2 gives an overview of our main informants and interviews.

Our second source of data were interviews and conversations with experts from the respective fields of our cases. We conducted six interviews with academic experts, and six interviews with industry experts. The style of these interviews ranged from short informal conversations (3 minutes) to longer in-depth discussions (30 minutes). Notes were taken either during the interview or written up directly after. These interviews helped to validate the statements from the primary interviews, and ensured that the conclusions drawn were correct. Table 3 provides an overview of these secondary interviews.

[Insert Table 2 and Table 3 here]

Our third source of data - archival data — was used to enrich the information gained from the interviews and for validation and mitigation of recall bias (Huber and Power, 1985).We analyzed annual reports for the publicly traded firms, i.e. Bauer and DMT, for the previous four years, and also external reports such as analysts' reports (Pfeifenberger and Akram, 2006; Stewart, 2006), the initial public offering prospectus (Deutsche Bank AG, 2006), and newspaper articles (Fasse, 2007; DMT, 2008). Two firms (Bauer and Wüwa) have company magazines which were also analyzed and provided data mainly on new products and details of internal and external company representation. We checked the press archives at firms' websites, equipment programs, and 
catalogues. Bauer and Teekanne also had books relating to their firms' history (Mayer, 2006; Stötzer et al., 2008; Teekanne GmbH \& Co. KG, 2007). In the case of Bauer, we had access to presentations at shareholders' meetings (e.g., Bauer AG, 2007). Finally, we scrutinized the available academic literature in the respective technology field (Buja, 2001, 2004; Kluckert, 1999; Stötzer and Schöpf, 2003).

\subsection{Data reduction and analysis}

Analysis of the documented material followed a structured and iterative approach based on Miles and Huberman (1994) and Gioa et al. (2013).

First, we applied open coding to the interview data, assigning codes to individual text passages. Some codes derived from our understanding of the prior literature regarding the commercialization of user innovations (Baldwin et al., 2006; Haefliger et al., 2010; Shah and Tripsas, 2007). We added new codes if we found relevant passages that were not covered by the existing codes. The outcome was a list of first order codes and a list of text passages and quotes relating to the codes.

In the next step, we cleaned up our coding structure. We checked whether all the quotes in one category were semantically similar across our data. We combined similar codes into common themes to avoid overlaps in categories, and discarded codes which were not pertinent to our research question. This resulted in a list of combined higher order codes.

In the next phase, we combined codes to aggregate dimensions (Gioia et al., 2013). These aggregate dimensions are a more abstract representation of the codes themselves and constitute the building blocks for our theory. We tried to link codes to emerging theoretical concepts, to identify how these concepts related to the outcomes analyzed. During this phase we constantly cycled between the emerging theoretical themes and the data and compared them for consistency (Glaser and Strauss, 1967). We used cross case comparison to analyze findings across cases. We set out 
our codes in matrices across cases and checked which findings were consistent and which were not (Miles and Huberman, 1994). In the case of doubt or need for more data we used mostly archival data to support the emerging theory because these data were readily available and could be assumed to be free from biases that might affect the retrospective accounts of our interviewees.

The final data structure was represented by 16 combined codes which aggregated to 5 categories: (1) stream of user innovations, (2) visibility and reputation in the original business, (3) conflicts, (4) investments for user innovations, and (5) asynchronous business cycles. Table 4 presents the data structure.

In the third step, in order to strengthen the reliability of our coding and the robustness of our findings, we asked an independent researcher to recode the text passages, using the aggregate code categories. We chose someone not involved in either the data collection or analysis to ensure an outsider perspective on our data (Gioia et al., 2013). He assigned the text passages to one of the six categories or to the category "other." We then checked to what extent the assigned categories overlapped. Table 4 shows that inter-rater agreement ranges between $94 \%$ and $97 \%$ across the categories. The average percentage of inter-rater agreement over all statements and categories is 94.8\% which is considered to be an acceptable value (Schmitt et al., 1991).

In the fourth step, we reviewed all the categories to develop our overall theoretical framework based on the documented material. This was an extensive process which was conducted in various joint meetings among the authors. The outcome was five propositions which make theoretical statements about the determinants of becoming a user-manufacturer innovator and successfully sustaining the duality of being a user-manufacturer innovator. Table 5 presents an overview of our propositions and how they are represented in the respective cases. For easier interpretation and to 
structure our findings we subsume these propositions under innovation, marketing, organization, and financial aspects.

\section{[Insert Table 4 and Table 5 here]}

\section{Findings}

In presenting our findings, we first provide an overview of the phenomenon of usermanufacturer diversification, focusing on the sequence of steps that we observed in the cases we studied. The following subsections then delve deeper in four specific aspects of the phenomenon, and derive propositions regarding the factors that influence user-manufacturer diversification. Our propositions relate to both the move toward and the successful sustainment of user-manufacturer diversification, since anticipation of ongoing benefits from diversification is, rationally, a motive for diversification. Table 5 and Figure 1 present and depict our five propositions.

\section{[Insert Figure 1 here]}

\subsection{The phenomenon: Overview}

We find that user-manufacturer diversification as a pathway to commercialization of user innovations is an emergent process rather than an intentional strategic decision from the outset (cf. Shah and Tripsas, 2007). The point of departure is a firm's original business in which it delivers goods or services to its customers, using specific machinery or equipment and being at the leading edge of its industry. We refer to this business as the user business or user unit. At some point, the firm then experiences specific problems during the production or service delivery process which it cannot solve with available technology. These problems can be severe, even threatening the firm's existence. The idiosyncrasy of these problems and the firm's being at the leading edge often imply that external markets do not offer satisfactory solutions. Thus, the firm starts to search for solutions internally, notably those employees who are facing the focal problems directly. Solution ideas are 
then turned into prototypes by the firm's maintenance or tooling department or the repair shop. By trial and error and close collaboration between the users and machinery designers the machines are optimized to suit the needs of the user business, and produced in small numbers for the firm's internal use. Note that these innovations represent process innovations for the user unit.

The commercial opportunity typically becomes visible as the firm uses its equipment in the field. In the construction business for instance often several firms, even competitors, work together on one construction site. Keeping an innovative machine or significantly improved process a secret is thus almost impossible. Soon after the development of the user innovation, other firms would approach the user innovator with requests to buy or rent it. The user innovator thus realizes the opportunity to commercialize its innovation. These requests are mostly rejected, however: the user business, deriving a competitive advantage from its superior technology, objects to strengthening its competitors.

This initial opposition to commercialization is eventually overcome, through a combination of opportunities and threats. Among other things, visibility of the innovation may encourage other manufacturers to develop similar machinery and supply them to the innovator's competitors (Henkel et al., forthcoming). For the innovator this would imply both a loss of competitive advantage in the user business and foregone sales. Further factors favoring the move toward commercialization are discussed in depth in the following subsections.

The process to full commercialization is often slow. As an intermediate step, the firm supplies only select customers, those that do not compete directly with its user business. This selectivity is often based on a geographic segmentation of the market. Eventually, the firm adopts a strategy of unrestricted commercialization of its user innovation, thus transitioning to a fully vertically integrated user-manufacturer. This step includes the institutionalization of the manufacturing 
business, e.g. by establishing a new group, business unit, or by organizing the user and the manufacturer business as different entities under one legal holding.

Once the manufacturing unit is established, the challenge arises of jointly managing the two units characterized by different business logics, occupational identities, and industry conventions. The manufacturing unit shifts its focus away from the user unit toward serving the needs of external customers. These customers being competitors of the user unit naturally implies difficult tradeoffs and potentially even severe internal conflicts. Diversification also shifts the balance of power in the organization from the user to the manufacturing unit. In the following subsections, we will discuss which factors favor successful user-manufacturer diversification and its sustainment.

\subsection{Innovation-related aspects of user-manufacturer diversification}

Urgent user needs were the initial driver of innovations that triggered diversification into manufacturing. In all four cases, firm employees faced difficulties when working on specific projects. As they were among the first in their respective domain to encounter these problems, no market offerings existed that would have provided satisfactory solutions. Thus, they were obliged to find a solution themselves, and since they could not rely on help from outside to do so, they had to mobilize resources from within the firm. They frequently consulted maintenance engineers responsible for maintaining or rehabilitating existing machinery. Jointly with these individuals, the users came up with sometimes rudimentary but workable solutions.

For Bauer, an urgent user need was to stabilize the walls of an excavation pit within a constrained space and under time pressure. This led to the development of a new technique for supporting the walls using injection anchors. Since no machine to install the anchors existed, Bauer's maintenance shop began to modify existing drilling tools. These machines did the job but it was realized that productivity could be increased with specialized machinery-which led to the 
inception of Bauer's dedicated manufacturing unit. ${ }^{1}$ Similarly, Teekanne required machines to portion and package tea in individual bags but there was no suitable packaging machines available. Management approached an employed machine fitter to design a machine, which resulted in the packaging machine "Pompadour" and its successor, "Reliance." DMT and Wüwa also experienced emerging needs with respect to geological exploration and tunneling respectively, for which no solutions were available. Both firms began building own tools to satisfy their needs. A Wüwa manager stated: "That's what prompted me to say 'Well, if I want to do something in this area, I'm going to have to help myself because there's simply nothing on the market.' And the whole thing developed from there: beginning with simple technology we tried to build channels in the pipe jacking method."

Successful development of innovations for in-house use brought the realization that the respective machines would also be useful to other firms. As users, our focal firms were able to assess the extent to which these machines would also solve other firms' problems. In the field of geological exploration, an informant from DMT stated: "We then started to develop vibration measuring devices, for our own use, of course, within the framework of the research project. And it just went on from there [...]. And after all this, around the mid-80s, we realized, well, there could be an interest from others and other countries in this. And then we began, you know, selling the first tools to China or Korea."

Other firms soon realized that Bauer's user innovations were superior to the machines being sold by other manufacturers which lacked the relevant user knowledge. These firms approached Bauer to buy its machines. A Bauer informant described how these requests helped to realize that

1 Only Bauer and Teekanne have separate manufacturing business units. However, this does not affect our findings. 
selling the machines would be a success: "This in turn, first of all, led relatively quickly to competition suddenly emerging in the area, and this resulted in, or meant that, of course, a bunch of our competitors suddenly came to us and said, hey guys, we'd actually prefer to have your machine than your competitors', so why not sell us yours?" Similarly, inquiries from competitors helped Wüwa to recognize the business opportunity related to these internally developed products.

For Teekanne, requests from potential buyers played an even bigger role. The firm had developed, built, and sporadically sold its "Pompadour" and "Reliance" tea packaging machines before WWII. After the war, a large US tea packaging firm-Lipton-became interested in Teekanne's newly developed, but not yet built, successor machines; their provision of finance made the production of these machines possible. The firm realized that systematic sales of its machines could become an attractive business.

Innovations originating from the firms' user businesses not only facilitated diversification into the respective machinery business, but also supported sustainable existence of the latter after its inception. As an interviewee from Teekanne reported: "So on the one hand, there is of course the pressure to innovate from Teekanne [i.e. the user unit], and then of course they always had further requirements. What can we improve here? [ ... ] So this is a source of innovation.”

Bauer emphasizes how the firm's overall orientation toward construction services facilitates its machinery innovations: "What sets us apart is precisely that we do both: we develop our machines very much from the [construction] process; and personnel rotate between engineering and construction to achieve a robust transfer of know-how. The fact that we have a culture in the company that draws its lifeblood from construction work and that our engineering people therefore also think in terms of construction methods." 
The need knowledge embodied in the user business is not only a source of innovation itself but also helps to understand and thus absorb ideas and need knowledge from external users and customers. As a result, the firm has a clear understanding of customer needs: "The special thing about Bauer is that we learnt to listen to our customers. Others don't do that. And this is the whole trick. The others say they already know. They do not understand the needs of the customers, because my customers, they are the same to me, they are also construction engineers. They tell me and I instantly understand what they mean." This facilitates the absorption of innovation ideas from customers once the firm diversified.

The ability to absorb external user needs helped Teekanne's manufacturing unit to innovate based on these needs. One informant reported: "The other source comes [...] from other customers [who] have their ideas and are, you know, also driven by the market. [ ... ] Then the idea or the pressure or need comes from the outside [...]." Wüwa specifically points out the importance of inhouse user knowledge for understanding user needs: "Our manufacturing engineers have to accumulate practical experience to understand the requirements for our machinery. They have to learn at the building site. It is impossible to describe the requirements in a way to just transfer them to someone else".

Our first proposition summarizes the above logic.

Proposition 1. A continuous stream of user innovations from the core business leads to the accumulation of deep user need and solution knowledge, which in turn favors the move toward and the success of user-manufacturer diversification through supplying product innovation ideas and generating absorptive capacity for external user needs.

We note that user innovations in the firm's core business are process innovations, and that a continuous stream of such user innovations can be expected only if process technology plays an important role in the user industry. 


\subsection{Marketing aspects of user-manufacturer diversification}

When our case firms entered the market as machinery sellers, they were already known to their prospective customers as competitors and - advanced and sophisticated - users of the machinery. They had a very good reputation in their respective original businesses, which facilitated their diversification by conveying credibility and legitimacy. Potential buyers respected them as specialists in the field and were familiar with the brand.

When Bauer entered the machinery market, the firm was well known for its deep user need knowledge in the specialist foundation engineering business. In combination with the high observability of construction services and the machines used in performing them, this created awareness for the Bauer brand. As a result, Bauer was hindered less by the typical market entry barriers such as access to customers and establishing credibility. Also when entering new markets as a machinery seller, for example in Asia, awareness of Bauer as a firm with long experience in the specialist foundation engineering business precedes this entry: "Of course it helps tremendously if Bauer is the strongest company in the market there, and drills the ears off the competition [...] These are great selling points. In markets where Bauer doesn't yet have a profile in specialist civil engineering, it's that much harder to build up a market for machines as when Bauer is already there. [...] So overall Bauer construction helps us sell equipment."

Also in the Teekanne case, potential buyers of its packaging machines knew the firm to be trustworthy due to its reputation as a user of its own machines before WWII. Customers purchased the first new machines after the war, even paying in advance without having inspected a working prototype, based solely on their knowledge of the output, i.e. the finished teabags. Teekanne's manufacturing unit continues to exploit the reputation of the user unit: "We even advertised with it!", as one of our interviewees stated. 
Similarly, Wüwa's management perceives the firm's activities in the construction business as a selling proposition for customers, since use of Wüwa's own machines on its construction sites demonstrates their functionality. One informant from Wüwa described the situation as follows: "We can profit from our own experiences, both negative and positive. You've got to learn your lessons from the negative experiences, too. I think that for many customers this leads to greater confidence because they say to themselves if they can use their own junk, in inverted commas, and still be successful, then it can't be that bad."

Finally, DMT reported benefits for its machinery business due to the interplay with its services. For example: "It's a similar situation with our surveying gyroscope, the Gyromat 3000 or 5000. The advantage is that the potential customers, who want to buy a measuring instrument, can buy the service beforehand, and that way get to know the instrument in detail in a practical setting. Usually this leads to a later purchase of the instrument so that they can then perform the measurements themselves." ${ }^{2}$

Summarizing the above arguments we posit that:

Proposition 2. Good reputation based on the firm's user business increases credibility and legitimacy of the manufacturing business, and thus facilitates the move toward and the success of user-manufacturer diversification.

2 An additional market-related aspect of user-manufacturer diversification concerns the risk of imitation by competing manufacturers. This risk, which Henkel et al. (forthcoming) analyze using a formal model, increases attractiveness of user-manufacturer diversification since, with imitation, the user innovator's competitive advantage from using the innovation vanishes in any case. We found evidence of this consideration for Teekanne and Wüwa, but not consistently across all cases. 


\subsection{Organizational aspects of user-manufacturer diversification}

In all four cases the establishment of the manufacturing unit as well as the coexistence of both units involved conflicts, both between the two units and between the focal firm and its customers. Before diversification, conflicts typically centered on the question of whether the firm's user innovations should be sold. Potential customers were more or less direct competitors of the user unit, and supplying superior machines to competitors would decrease the user unit's competitive advantage.

For Bauer, the decision to commercialize its user innovations was difficult and reached only after long, controversial discussions. Many employees were critical of Bauer's selling machines to direct competitors in the construction business: "People developed these machines themselves [...] and they were proud of them [...]. And suddenly the competition got them. Simply because they were richer." This resulted in resistance to the establishment of a new manufacturing unit: "The resistance was straightforward: 'We sell our know-how.' What we do here is enough, we don't need mechanical engineering, to manufacture and sell equipment, we need to manufacture machines for ourselves." These conflicts continued to some degree even after the manufacturing unit was set up.

To avoid conflicts between the units, the firms started by selling their inventions selectively. Bauer initially only supplied handpicked firms with which it had close relations, although the firm later relaxed this restriction. Teekanne and DMT tried to mitigate potential conflicts by segmenting the market geographically, selling their user innovations only to markets which were distant from their German home market (overseas for Teekanne, Asia for DMT).

Conflicts between the two units may also originate from customers. For example, when Bauer's construction unit was perceived as behaving too aggressively by its competitors, these would ask 
the manufacturing unit to intervene. As the managing director of the machinery unit stated: "But then of course Bauer [construction] stirred things up again. It's obvious, because they're taking orders away from our dear customers. Then they [the customers] call me and say I should tell the construction unit to keep their hands off. [...] I've got nothing to say about that, I manufacture machines, the others do the construction, and if you have a problem with Bauer regarding construction, then call them yourself."

Competition between customers and the focal firm's own user unit for the resources of its manufacturing unit was another potential source of conflict. For Wüwa and DMT, interviewees reported that when both internal and external customers required maintenance services it was necessary to prioritize. External customers often received preference; the internal units were expected to help themselves and to be patient. An informant from DMT described it thus: "Our measurement service group is stranded somewhere on a mountain and needs help, and of course it's sometimes 'Unfortunately, there's nothing we can do for you, we've got to take care of the customers who buy our equipment, you're going to have to muddle through.' It's not meant unkindly, they just don't have the time for it; there's always a solution of some sort, but there are going to be problems when the external customer for equipment gets preference over the internal department."

Despite these conflicts, all case firms reported that the advantages of diversification outweigh its downsides. Bauer's management even considers the tensions a source of competitive advantage, and is convinced that they do not prevent a constructive working relationship between the two units. The synergies are perceived as dominant: "It's good to have these synergies, this mutual learning. And also, incidentally, the in-house competition which arises from it. It's fascinating how the mechanical engineers suddenly try to be the better civil engineers, and the civil engineers try 
to be the better mechanical engineers, since our construction company also still has a crafts workshop. [...] And so this creates a brilliant interplay that drives the company forward."

The following proposition summarizes our argument:

Proposition 3. User-manufacturer diversification entails inherent conflicts between the user and manufacturer businesses, which hinders both the move toward and the success of user-manufacturer diversification.

\subsection{Financial aspects of user-manufacturer diversification}

When firms start to develop machinery or tools to resolve the problems encountered as users, they need to invest in product development. As soon as they realize that the resulting innovations could be valuable to other user firms, they anticipate that commercializing these innovations would allow spreading the investment across bigger volumes, and benefitting from economics of scale.

In the case of Bauer, the grouted tieback anchor and other early machinery innovations increased the productivity of the construction business but involved heavy investments. Knowing that others would also profit from these innovations, Bauer realized that selling the machines would help to amortize these investment costs. The rationale was similar in the cases of Wüwa and DMT: being able to spread development costs over a larger number of units was an important motive for the commercialization decision.

In the case of Teekanne, the introduction of advanced machines was only possible because they were already commercialized. After WWII, Teekanne had the knowledge to build machines, and also designed new machines for its own production and packaging. However, it did not have sufficient financial resources to cover the necessary investments. Lipton showed interest and paid for the machines in advance. These payments not only covered the internal investment, it gave the firm a head start in the years of the German "Wirtschaftswunder." One informant described the 
situation: “[...] After the war there wasn't the money to invest very much. If the Lipton people hadn't said, 'We'll buy the first machines from you and make a contract with you to get the first machine; for this you'll get so and so many dollars,' I don't think things would've worked out so well or so quickly with the ... with the machine."

Also after the step to diversification and establishment of a manufacturing unit, the expectation of recouping investments through external sales promoted innovations at the case firms and thus made diversification sustainable. The firms relied on the returns from commercialization to cover the $R \& D$ investments needed for their user innovations.

Bauer made considerable investments for each new development project; however, its construction business customers, being interested in the end result only (e.g., an excavation pit), were not willing to bear the development costs of specialized, high-end construction machines. Thus, the higher the investments required the more it made sense to spread them over a large number of units to reduce per-unit development costs. This became particularly urgent as a result of intensifying competition in the construction business and increased development costs.

Wüwa, also in the construction business, experienced a similar situation. Selling machines helps to cover earlier investments. Only rarely was a project which required investments able to completely recoup the investments: "Also of course there are then investment needs and I have to think about how I can pay them off, and where I see the potential. If I happen to have a very lucrative engineering contract and I know, ok, now I need this or that and I can cover it with a single engineering contract, well that, of course, is a very nice situation, which doesn't come along too often."

By selling the machines to its competitors, DMT is able to cover the investment for the development of the machines, which was particularly important in the early days of DMT's 
manufacturing business. The firm currently uses the additional revenues to finance its product development initiatives: "We have also always set a certain proportion of our turnover aside for new innovation; there was once a time when we put money aside for a new development, and since then development happens automatically because where we see an opportunity for development, we simply fund it from our war chest." Similarly, Teekanne nowadays deploys the returns from its machine sales to finance its current quite large R\&D spending. Combining the above arguments leads to Proposition 4:

Proposition 4. Higher investments in user innovations entail a more urgent need to recoup these investments and thus favor both the move toward and the success of usermanufacturer diversification.

Another financial aspect of user-manufacturer diversification relates to asynchronous business cycles between the user and the manufacturing businesses. Consider the case of Bauer. In 1984, the firm's construction business had not been sufficiently profitable for many years, so the need for additional revenue sources was urgent. After years of selective sales of its user innovations, expanding its machinery sales appeared a viable option. The former managing director of Bauer's manufacturing business described the situation thus: "In the end, the economic situation forced our hand. If things had gone well for us in the construction industry, so that we wouldn't have had to build machines, then we wouldn't have expanded machine manufacturing to the same extent." 3

Asynchronous business cycles offer firms the option to subsidize one unit in case of downturns in the earnings from the other. DMT spreads the risk of its geo-exploration unit by offering its

3 While it may seem surprising that the machinery and the construction business cycles are asynchronous, according to our interviewees this is indeed the case for Bauer. 
services across different regions. Thus, this business is relatively stable, and in turn buffers the volatility of device sales.

Similarly, Teekanne's user unit helps out its counterpart when necessary, by adjusting investment decisions. When excess production is not being sold, the user unit may bring forward the purchase of new machines to fill gaps in demand. One informant told us: "Of course maybe in years when there's a slump on the machine side, of course, then perhaps orders from Teekanne can steer things a bit. You say, 'We'll use this year what might otherwise have been an investment for next year, in order to fill in the gaps now,' that's obvious."

The fact that diversification can buffer against market cyclicality is well known. What is new, and in fact surprising, is that this mechanism matters in the context of user-manufacturer diversification, since the two industries under consideration are closely related and thus could be expected to be in sync. These considerations lead to Proposition 5:

Proposition 5. A firm's original user business and its new manufacturing business may follow asynchronous business cycles. In that case, market cyclicality favors both the move toward and the success of user-manufacturer diversification.

\section{Discussion}

\subsection{Comparing pathways of commercialization of user innovations}

In order to further characterize user-manufacturer diversification as a phenomenon we compare it with the two other known pathways to user innovation commercialization (Agarwal and Shah, 2014; Baldwin et al., 2006; Haefliger et al., 2010; Hienerth, 2006; Shah and Tripsas, 2007) along six dimensions, as shown in Table 6.

The comparison reveals that user-manufacturer diversification shares some characteristics with both of the known pathways, yet differs in others. Similarities between user-manufacturer 
diversification and user entrepreneurship are that, in both cases, the need knowledge underlying the user-driven innovation resides within the focal organization or its founder, which reduces transaction costs for identifying and assimilating this knowledge and gives rise to synergies between the user and the manufacturer function.

As a difference between user-manufacturer diversification and user entrepreneurship regarding the locus of need knowledge and innovative activity we conjecture that the former is more likely if the innovation requires a larger team effort supported by the firm and if it is specific to the user industry. In our cases, it would have been difficult or impossible for an individual user innovator, or even a small team, to leave the firm and commercialize the innovation through a start-up. ${ }^{4}$

With respect to complementary assets, user-manufacturer diversification is more akin to new product introduction by an established manufacturer in that an existing organization, financial resources, and a brand are already in place. Unlike the user entrepreneur, the user-manufacturer does not suffer from liabilities of newness and smallness, even though both need to build up manufacturing capacity and distribution channels.

User-manufacturer diversification is unique compared to both other pathways as regards the relationship with other firms. Competing manufacturers are actual or potential suppliers to the user-

4 As a counter-example, consider the case of "Efficient Elements" (https://www.efficient-elements.com/). The founder of this firm, Felix Dollinger, developed a software add-in to Microsoft PowerPoint while working with Siemens Management Consulting (SMC). He developed his software product largely by himself rather than with a larger team; also, it is useful to any organization, not just management consultants, Thus, it is consistent with our argument that Dollinger became an independent user entrepreneur rather than SMC diversifying into software. 
manufacturer's user unit, while customers of the manufacturing unit are competitors of the user unit. ${ }^{5}$ Also the concomitant internal conflicts are unique to the case of user-manufacturer diversification, since a user entrepreneur is often not competing with other users (and may also give up the user role for good).

[Insert Table 6 here]

\subsection{Relation to existing research}

\subsubsection{The user-manufacturer and the boundaries of the firm}

The question of which activities should be governed within the organizations and which should be left to the market is central to management theory (Zenger et al., 2011) and addressed by an array of theories (Santos and Eisenhardt, 2005). We link our phenomenon to the two main theories explaining the scope of the firm (Madhok, 2002; Santos and Eisenhardt, 2005), i.e., to transaction cost economics and the resource-based view.

From a transaction cost perspective (Williamson, 1973) firms should govern a given activity inside the organization if the resulting transaction costs are lower than via market transactions. The latter become more costly with an increasing risk of opportunism and small numbers bargaining, which in turn are driven by asset specificity and information asymmetry. When user firms experience emerging needs and try to come up with solutions, they are the first and only ones facing

5 The airline reservation system, Sabre, is a case in point. Developed by American Airlines and IBM and owned by American for many years (https://en.wikipedia.org/wiki/Sabre \%28computer_system\%29), it is an example of user-manufacturer diversification in the ICT/services sector. Sabre was also used by travel agents and (few) other airlines, but favored American over its competitors. This bias made American's user-manufacturer diversification unsustainable in the long run, and contributed to the eventual spin-off of Sabre from American in 2000. 
these new problems, a situation that implies asset specificity and information asymmetry. Thus, from a transaction cost perspective, vertical governance and integration of equipment manufacturing should be advantageous.

The arguments from the resourced based view (Barney, 1991; Wernerfelt, 1984) focus on synergies between resources (Conner, 1991): firm boundaries should be set in a way that maximizes the value of the respective resource bundles (Santos and Eisenhardt, 2005). This argument speaks for internal governance of activities that require resources already available within the firm (Santos and Eisenhardt, 2005). More generally, a success factor in vertical diversification is the degree of relatedness of the businesses involved. Two businesses are "related to one another when a common skill, resource, market, or purpose applies to each" (Rumelt, 1974, p. 29). It has been argued that relatedness is especially important in cases of vertical diversification through internal development (Busija et al., 1997). Relatedness in general (Montgomery, 1994; Palich et al., 2000), and vertical relatedness in particular (Pennings et al., 1994) are positively related to diversification performance.

We argue for our case that the resources deployed in the user business and in the manufacturer business represent a bundle of complementary resources that interact in fostering firm performance (Song et al., 2005). Specifically, these resources are need and solution knowledge, brand recognition, and an established organization. Regarding knowledge, scholars have generally argued that hierarchy is a more efficient governance mode than markets if intensive communication and combinative capabilities are required (Kogut and Zander, 1992). These considerations speak in favor of user-manufacturer diversification. 


\subsubsection{Propositions in the light of existing theory}

Proposition 1 states that a continuous stream of user innovations favors user-manufacturer diversification through supplying product innovation ideas and generating capacity to absorb external need knowledge. Prior research on end-user innovators finds a similar pattern, both regarding the lead-userness of the innovator and the importance of feedback from a community (Franke and Shah, 2003; Franke et al., 2006; Hienerth, 2006; Shah and Tripsas, 2007). Similarly, diversity of needs among internal and external users favors user entrepreneurship in our study as well as in the literature (Shah and Tripsas, 2007), though interestingly in different ways. While external feedback helps the firms in our sample constructing machines each of which satisfies diverse needs, Shah and Tripsas (2007) propose that high variety in needs favors user entrepreneurship by creating numerous niche markets for differentiated user innovations.

According to Proposition 2, the marketing of commercialized user innovations is facilitated by the reputation and credibility of the original user unit, which extends to the manufacturing unit upon diversification. This finding resonates with institutional theory (Aldrich and Fiol, 1994; Suchman, 1995), which states that such legitimacy is key to the success of an organization. Accordingly, new entrants associated with diversifying incumbents can profit from the legitimacy of the incumbent (York and Lenox, 2013), in particular in the case of related diversification. Proposition 2 is also in line with research on marketing and branding. Here, scholars have shown that extending brands to another product category is especially successful if the original and the new product domain are complementary to each other (Aaker and Keller, 1990; Bottomley and Holden, 2001). This is the case for user-manufacturer diversification.

Proposition 3 addresses tensions and conflicts concomitant to user-manufacturer diversification. It is in line with social identity theory, which explores how conflicts between 
different identities affect the organization (Ashforth and Mael, 1989; He and Brown, 2013). Such conflicts may relate to unit membership, but are rooted in conflicting goals, beliefs, values, and behaviors that underlie the identities (Ashforth et al., 2008). To overcome these conflicts and to converge identities, firms need to apply integration mechanisms (Ashforth et al., 2008; He and Brown, 2013). Indeed, most of the firms in our study have mechanisms in place to mitigate conflicts between the two units. In Teekanne, the boundaries between the units are porous, and trainees get to know both units and their respective viewpoints. To manage conflicts and to turn them into a stimulating internal competition, Bauer's senior management intensively communicates and thus integrates the two units at the management level. This ensures that both units follow an integrated corporate strategy and are not diverted by unit-specific substrategies.

Proposition 4 states that high investments in user innovations favor user-manufacturer diversification because they entail an urgent need to recoup these investments. It complements Baldwin et al.'s (2006) suggestion that the amount of capital that an end-user manufacturer invests in an innovation project drives the quality of the resulting product and thus creates competitive advantage. While Baldwin et al. (2006) refer to the quality-enhancing effect of investments in user innovation, we focus on the need to recoup these investments. A further parallel to Baldwin et al.'s (2006) study concerns the shift, concomitant to the maturing of a market created by user entrepreneurship, from high-variable, low-capital cost production to high-capital, low-variable cost manufacturing. While the individual users in their study differ significantly from the user firms that we analyze, the establishment of a manufacturing unit goes along with the same shift.

Proposition 5, finally, stating how cyclicality of the user and the manufacturing business favor user-manufacturer diversification mirrors general recommendations from portfolio management theory (Markowitz, 1991; Meskendahl, 2010). 


\section{Conclusions}

\subsection{Contributions}

Our research makes three contributions to the literature. First, we contribute to the body of literature that explores how user innovations are commercialized by users (Baldwin et al., 2006; Haefliger et al., 2010; Shah and Tripsas, 2007). We demonstrate that, under certain conditions, user-manufacturer diversification and subsequent coexistence of both functions within one firm is feasible. Such diversification constitutes a new pathway to commercializing user innovations.

Second, we carve out the factors that favor or hinder user-manufacturer diversification. Our contribution lies in showing that these are the factors relevant in promoting user-manufacturer diversification, and in establishing the overall combination of factors at work. It is worth noting that the majority of the factors are linked to the firm's lead user characteristics (von Hippel, 2005). Being a lead user implies more internal user innovations (Proposition 1); entails a good reputation of the user unit in its industry (Proposition 2); and makes more radical and thus more costly user innovations likely (Proposition 4).

Third, we contribute to the literature linking integration of external knowledge, strategy, and firm boundaries (e.g. Baldwin and von Hippel, 2011; Tushman et al., 2012). This work predicts that innovation is likely to happen where knowledge is sticky (von Hippel, 1994). Yet, most research implicitly assumes that knowledge about latent user needs is located outside the organization producing the focal good. Our cases challenge this assumption. We observe that user innovation can provide the impetus for vertical diversification, which is further facilitated by the original unit's reputation and legitimacy. User innovation thus affects one of the central strategic decisions of the organization, about where to draw its boundaries. 


\subsection{Implications for practice}

Our findings bear implications for practice. First and foremost, we show that vertical diversification based on internal user innovation may be worthwhile. User ideas for process innovations abound in many organizations and may represent valuable commercial opportunities. Yet, they are often not recognized as such (de Jong and von Hippel, 2009). The success factors we identified can help managers to evaluate the option of commercializing these user innovations through user-manufacturer diversification. In so doing, managers should regard the standard recommendation "to focus on core competences" with caution, since user-manufacturer diversification is a rather specific type of related vertical diversification.

Managers should also consider possible downsides of user manufacturer diversification. We showed that tensions may arise between the user and the manufacturing unit, and possibly also with customers of the latter. Managers should thus try to align the goals of both units by formulating and communicating an integrated strategy with common long-term goals, and should promote social interaction and porous boundaries between the units. Regarding competitors of the user unit, managers of the manufacturing branch must make sure to treat them in a fair way and not to discriminate in favor of their internal customers.

Also communication matters. Banks, shareholders, and consultants often prefer a strategy of focusing on core competencies. Thus, it is paramount to clearly communicate the benefits of usermanufacturer diversification to external stakeholders.

\subsection{Limitations and future research}

Our study has several limitations. First, as most case-based research it might suffer from retrospective bias. However, since we complemented the interviews with various other types of sources of information this bias should be minimal. Second, the propositions we derive are based 
on cases from four industries, which raises the question of external validity. While the diversity of our industries makes us confident that the propositions are not idiosyncratic (and examples of usermanufacturer diversification in industries not studied here ${ }^{6}$ support this view), it would be insightful to study user-manufacturer diversification in a large-scale cross-industry study to analyze contextual factors such as corporate governance, firm culture, industry structure, and home country. A third limitation is that we focus on firms that did become user-manufacturer innovators. A broader study could include non-diversifying user firms and compare them to those that do diversify.

In future work, industry-wide studies could also analyze how user innovation affects industry structure, and the relation between user-manufacturer innovators and competitors in either industry. Roy and Narkar (2015) make first efforts in this direction and show that robotics firms with inhouse users are more likely to switch successfully to new technological paradigms than firms without in-house user knowledge.

6 In the chemical industry, many firms (e.g., Linde and AirLiquide) sell products and also the process plants to produce them. Van Rooij (2005), in his study of the diffusion of ammonia process technology in the $20^{\text {th }}$ century, finds that several firms in that industry both produced ammonia and sold the technology to other manufacturers. In the ICT industry, Munich-based innosabi GmbH offers "software and services for collaborative innovation management and crowdsourcing" (https://innosabi.com/en/contact/). Starting from Internet-based innovation services using inhouse-developed software, the firm diversified into a product business, offering its software platform to other firms including competing innovation intermediaries. The Sabre airline reservation system (see Footnote 5) offers a further example from the ICT sector. Also in our focal industries there are further examples of user-manufacturer innovators; Italy-based TREVIGroup, for example, resembles Bauer AG in many respects (www.trevigroup.com). 
Related to user entrepreneurship, a central question for future research appears to be the competition between individual-level user entrepreneurship and user-manufacturer diversification. We conjecture that user innovations within firms are more likely to lead to user-manufacturer diversification than to user entrepreneurship if the innovation requires a larger team effort within the firm and broad technical knowledge, if its complexity is high, and if the innovation is specific to the user industry. Also the type of organization should matter. Hospitals, medical practices, universities, and research institutions are known as prolific sources of user innovation (Hinsch et al., 2014; Lettl et al., 2006; von Hippel, 1976), but are not likely to diversify vertically into manufacturing. In these settings, user entrepreneurship or the transfer to existing manufacturers appear more likely. With these and other unanswered questions, we believe our study opens interesting avenues for future research. 


\section{References}

\section{Cited archival data}

Bauer AG, 2007. Präsentation zur Hauptversammlung. Schrobenhausen.

Buja, H.O., 2001. Handbuch des Spezialtiefbaus - Geräte und Verfahren (2nd ed.). Werner Verlag, Düsseldorf.

Buja, H.O., 2004. Der Spezialtiefbau - Aktueller Stand der Geräte- und Verfahrenstechnik. Bautechnik Spezial 81, 25-109.

Creditreform, 2010. Auskunft über DMT GmbH \& Co. KG, from January 6th, Essen.

Deutsche Bank AG, 2006. Börsenprospekt der Bauer AG. Schrobenhausen, Frankfurt am Main.

DMT GmbH \& Co. KG, 2011. Unternehmensprofil der DMT. Essen.

Fasse, M., 2007. Der Tiefenwurzeler, In: Handelsblatt, from August 3rd, p. 13.

Kluckert, K.D., 1999. Rückblick auf 40 Jahre Bohrpfahltechnik - Gibt es noch Impulse für die Zukunft? Tiefbau 111, 332-341.

Max Bögl Bauservice GmbH und Co. KG, 2003. Wüwa Bau als Neumaschinenbauer. Kundenmagazin Max Bögl.

Max Bögl Bauservice GmbH und Co. KG, 2009. Wüwa feiert 25-jähriges Firmenjubiläum. Mitarbeiterzeitung Max Bögl.

Mayer, F.J., 2006. Bauer - Geschichte und Geschichten. Bauer AG, Schrobenhausen.

Pfeifenberger, M., Akram, I., 2006. Bauer AG - on the right foundations; Initiate with buy. Deutsche Bank AG, Company Research. Initiation of Coverage, 24 August 2006.

Stewart, A., 2006. Bauer - Plenty of Value to be Unearthed. Dresdner Kleinwort, Equity Research. Initiating coverage, 24 October 2006.

Stötzer, E., Schöpf, M., 2003. Drehbohrtechnik - Eine Multifunktionstechnik im Spezialtiefbau. Tiefbau 115, 338-344.

Stötzer, E., Schöpf, M., Mayer, F.J., Englert, K., 2008. Spezialtiefbau - Bautechnik, die begeistert. Schrobenhausen.

Teekanne GmbH \& Co. KG, 2007. 125 Jahre Teekanne. Düsseldorf. 


\section{Scholarly references}

Aaker, D.A., Keller, K.L., 1990. Consumer evaluations of brand extensions. Journal of Marketing 54.

Adegbesan, J.A., 2009. On the Origins of Competitive Advantage: Strategic Factor Markets and Heterogeneous Resource Complementarity. Academy of management review 34, 463-475.

Agarwal, R., Shah, S.K., 2014. Knowledge sources of entrepreneurship: Firm formation by academic, user and employee innovators. Research policy 43, 1109-1133.

Aldrich, H.E., Fiol, C.M., 1994. Fools rush in? The institutional context of industry creation. Academy of management review 19, 645-670.

Alexander, C., 1964. Notes toward a synthesis of form. Harvard University Press, Cambridge.

Allen, R.C., 1983. Collective invention. Journal of Economic Behavior and Organization 4, 1-24.

Ashforth, B.E., Harrison, S.H., Corley, K.G., 2008. Identification in organizations: An examination of four fundamental questions. Journal of management 34, 325-374.

Ashforth, B.E., Mael, F., 1989. Social identity theory and the organization. Academy of management review 14, 20-39.

Athaide, G.A., Meyers, P.W., Wilemon, D.L., 1996. Seller-buyer interactions during the commercialization of technological process innovations. Journal of Product Innovation Management 13, 406-421.

Baldwin, C.Y., Hienerth, C., von Hippel, E., 2006. How user innovations become commercial products: A theoretical investigation and case study. Research policy 35, 1291-1313.

Baldwin, C.Y., von Hippel, E., 2011. Modeling a paradigm shift: From producer innovation to user and open collaborative innovation. Organization Science 22, 1399-1417

Barney, J.B., 1991. Firm resources and sustained competitive advantage. Journal of management $17,99-120$.

Barney, J.B., 2001. Is the resource-based "view" a useful perspective for strategic management research? Yes. Academy of management review 26, 41-56.

Bottomley, P.A., Holden, S.J., 2001. Do we really know how consumers evaluate brand extensions? Empirical generalizations based on secondary analysis of eight studies. Journal of marketing research 38, 494-500.

Busija, E.C., O’Neill, H.M., Zeithaml, C.P., 1997. Diversification strategy, entry mode, and performance: Evidence of choice and constraints. Strategic Management Journal 18, 321-327.

Cantwell, J., Gambardella, A., Granstrand, O., 2011. The economics and management of technological diversification. Routledge.

Chatterji, A.K., Fabrizio, K., 2012. How do product users influence corporate invention? Organization Science 23, 971-987.

Chatterji, A.K., Fabrizio, K.R., 2013. Using users: When does external knowledge enhance corporate product innovation? Strategic Management Journal published online first. 
Conner, K.R., 1991. A historical comparison of resource-based theory and five schools of thought within industrial organization economics: do we have a new theory of the firm? Journal of management 17, 121-154

de Jong, J.P.J., von Hippel, E., 2009. Transfers of user process innovations to process equipment producers: A study of Dutch high-tech firms. Research policy 38, 1181-1191.

DeMonaco, H.J., Ali, A., Hippel, E., 2006. The Major Role of Clinicians in the Discovery of OffLabel Drug Therapies. Pharmacotherapy: The Journal of Human Pharmacology and Drug Therapy 26, 323-332.

Denzin, N.K., 1970. The research act in sociology: a theoretical introduction to sociological methods. Butterworths, London

Douthwaite, B.K., J.D.H., Park, J.R., 2001. Why promising technologies fail: The neglected role of user innovation. Research policy 30, 819-836.

Edmondson, A.C., McManus, S.E., 2007. Methodological fit in management field research. Academy of management review 32, 1155-1179.

Eisenhardt, K.M., 1989. Building theories from case study research. Academy of management review 14, 532-550.

Eisenhardt, K.M., 1991. Better stories and better constructs - the case for rigor and comparative logic. Academy of management review 16, 620-627.

Eisenhardt, K.M., Graebner, M.E., 2007. Theory building from cases: Opportunities and challenges. Academy of Management Journal 50, 25-32.

Franke, N., Shah, S., 2003. How communities support innovative activities: an exploration of assistance and sharing among end-users. Research policy 32, 157-178.

Franke, N., von Hippel, E., 2003. Satisfying heterogeneous user needs via innovation toolkits: The case of Apache security software. Research policy 32, 1199-1215.

Franke, N., von Hippel, E., Schreier, M., 2006. Finding commercially attractive user innovations: A test of Lead-User Theory. Journal of Product Innovation Management 23, 301-315.

Gioia, D.A., Corley, K.G., Hamilton, A.L., 2013. Seeking qualitative rigor in inductive research: Notes on the Gioia methodology. Organizational Research Methods 16, 15-31.

Glaser, B.G., Strauss, A.L., 1967. The discovery of grounded theory: Strategies for qualitative research. DeGruyter, New York.

Haefliger, S., Jäger, P., Von Krogh, G., 2010. Under the radar: Industry entry by user entrepreneurs. Research policy 39, 1198-1213.

Harhoff, D., Henkel, J., von Hippel, E., 2003. Profiting from voluntary information spillovers: How users benefit by freely revealing their innovations. Research policy 32, 1753-1769.

Harrigan, K.R., 1984. Formulating vertical integration strategies. Academy of management review 9, 638-652. 
Harrison, J.S., Hitt, M.A., Hoskisson, R.E., Ireland, R.D., 1991. Synergies and Post-Acquisition Performance: Differences versus Similarities in Resource Allocations. Journal of management 17, 173-190.

Harrison, S.H., Corley, K.G., 2011. Clean climbing, carabiners, and cultural cultivation: Developing an open-systems perspective of culture. Organization Science 22, 391-412.

He, H., Brown, A.D., 2013. Organizational identity and organizational identification: A review of the literature and suggestions for future research. Group \& Organization Management 38, 335 .

Heiskanen, E., Hyysalo, S., Kotro, T., Repo, P., 2010. Constructing innovative users and userinclusive innovation communities. Technology Analysis \& Strategic Management 22, 495511.

Henkel, J., Bock, A., Block, J.H., forthcoming. Selling to competitors? - Competitive implications of user-manufacturer integration, in: Harhoff, D., Lakhani, K. (Eds.), Revolutionizing innovation - Users, communities and open innovation. MIT Press, Cambridge.

Hienerth, C., 2006. The commercialization of user innovations: The developement of the rodeo kayak industry. R\&D Management 36, 273-294.

Hinsch, M.E., Stockstrom, C., Lüthje, C., 2014. User Innovation in Techniques: A Case Study Analysis in the Field of Medical Devices. Creativity and innovation management 23, 484494.

Huber, G.P., Power, D.J., 1985. Retrospective reports of strategic-level managers - Guidelines for increasing their accuracy. Strategic Management Journal 6, 171-180.

Kogut, B., Zander, U., 1992. Knowledge of the firm, combinative capabilities, and the replication of technology. Organization Science 3, 383-397.

Leonard-Barton, D., 1992. Core capabilities and core rigidities: A paradox in managing new product development. Strategic Management Journal 13, 111-125.

Leonard, D., 1995. Wellspring of knowledge. Harvard Business School Press, Boston.

Lettl, C., Gemünden, H.G., 2005. The entrepreneurial role of innovative users. Journal of Business and Industrial Marketing 20, 339-345.

Lettl, C., Herstatt, C., Gemünden, H.G., 2006. Users' contributions to radical innovation: Evidence from four cases in the field of medical equipment technology. R\&D Management $36,251-271$.

Madhok, A., 2002. Reassessing the fundamentals and beyond: Ronald Coase, the transaction cost and resource-based theories of the firm and the institutional structure of production. Strategic Management Journal 23, 535-550.

Markowitz, H.M., 1991. Foundations of portfolio theory. The journal of finance 46, 469-477.

Meskendahl, S., 2010. The influence of business strategy on project portfolio management and its success - a conceptual framework. International Journal of Project Management 28, 807-817. 
Meyers, P.W., Athaide, G.A., 1991. Strategic mutual learning between producing and buying firms during product innovation. Journal of Product Innovation Management 8, 155-169.

Meyers, P.W., Sivakumar, K., Nakata, C., 1999. Implementation of industrial process innovations: factors, effects, and marketing implications. Journal of Product Innovation Management 16, 295-311.

Miles, M.B., Huberman, A.M., 1994. Qualitative data analysis : an expanded sourcebook. Sage, Thousand Oaks.

Montgomery, C.A., 1994. Corporate diversification. The Journal of Economic Perspectives, 163178.

Palich, L.E., Cardinal, L.B., Miller, C.C., 2000. Curvilinearity in the diversification-performance linkage: an examination of over three decades of research. Strategic Management Journal 21, $155-174$.

Pennings, J.M., Barkema, H., Douma, S., 1994. Organizational learning and diversification. Academy of Management Journal 37, 608-640.

Roy, R., Sarkar, M.B., 2015. Knowledge, firm boundaries, and innovation: Mitigating the incumbent's curse during radical technological change. Strategic Management Journal, n/an/a.

Rumelt, R.P., 1974. Strategy, structure, and economic performance. Harvard Business School Press, Boston, MA.

Santos, F.M., Eisenhardt, K.M., 2005. Organizational boundaries and theories of organization. Organization Science 16, 491-508.

Schmitt, N., Klimoski, R.J., Ferris, G.R., Rowland, K.M., 1991. Research methods in human resources management. South-Western Publishing Company.

Schweisfurth, T.G., Raasch, C., 2015. Embedded lead users-The benefits of employing users for corporate innovation. Research policy 44, 168-180.

Shah, S.K., Smith, S.W., Reedy, E., 2012. Who are user entrepreneurs? Findings on innovation, founder characteristics, and firm characteristics. Kauffman Firm Survey, Kauffman Foundation, February.

Shah, S.K., Tripsas, M., 2007. The accidental entrepreneur: The emergent and collective process of user entrepreneurship. Strategic Entrepreneurship Journal 1, 123-140.

Siggelkow, N., 2007. Persuasion with case studies. Academy of Management Journal 50, 20.

Song, M., Droge, C., Hanvanich, S., Calantone, R., 2005. Marketing and technology resource complementarity: an analysis of their interaction effect in two environmental contexts. Strategic Management Journal 26, 259-276.

Strauss, A.L., Corbin, J.M., 1990. Basics of qualitative research: grounded theory procedures and techniques, 1. print. ed. Sage, Thousand Oaks.

Suchman, M.C., 1995. Managing legitimacy: Strategic and institutional approaches. Academy of management review 20, 571-610. 
Tushman, M., Lakhani, K.R., Lifshitz-Assaf, H., 2012. Open innovation and organization design. Journal of Organization Design 1, 24-27.

van Rooij, A., 2005. Why do firms acquire technology?: The example of DSM's ammonia plants, 1925-1970. Research policy 34, 836-851.

von Hippel, E., 1976. The dominant role of users in the scientific instrument innovation process. Research policy 5, 212-239.

von Hippel, E., 1986. Lead users: A source of novel product concepts. Management Science 32, 791-805.

von Hippel, E., 1987. Cooperation between rivals: Informal know-how trading. Research policy 16, 291-302.

von Hippel, E., 1988. The sources of innovation. Oxford. Univ. Press, New York, NY.

von Hippel, E., 1994. "Sticky information" and the locus of problem solving: Implications for innovation. Management Science 40, 429-439.

von Hippel, E., 2005. Democratizing innovation. MIT Press, Cambridge.

von Hippel, E., Thomke, S., Sonnack, M., 1999. Creating breakthroughs at 3M. Harvard Business Review 77, 47-57.

Wadell, C., Sandström, G.Ö., Björk, J., Magnusson, M., 2013. Exploring the incorporation of users in an innovating business unit. International Journal of Technology Management 61, 293-308.

Wernerfelt, B., 1984. A resource-based view of the firm. Strategic Management Journal 5, 171180.

Weterings, A., Koster, S., 2007. Inheriting knowledge and sustaining relationships: What stimulates the innovative performance of small software firms in the Netherlands? Research policy $36,320-335$.

Williamson, O.E., 1973. Markets and hierarchies: some elementary considerations. American Economic Review 63, 316-325.

Winston Smith, S., Shah, S.K., 2013. Do Innovative Users Generate More Useful Insights? An Analysis of Corporate Venture Capital Investments in the Medical Device industry. Strategic Entrepreneurship Journal 7, 151-167.

Yin, R.K., 2003. Case study research: Design and methods, 3. ed. Sage, Thousand Oaks.

Yip, G.S., 1982. Diversification entry: Internal development versus acquisition. Strategic Management Journal 3, 331-345.

York, J.G., Lenox, M.J., 2013. Exploring the sociocultural determinants of de novo versus de alio entry in emerging industries. Strategic Management Journal.

Zenger, T.R., Felin, T., Bigelow, L., 2011. Theories of the firm-market boundary. The Academy of Management Annals 5, 89-133. 


\section{Tables and Figures}

\begin{tabular}{|c|c|c|c|c|}
\hline & Bauer & DMT & Teekanne & Wüwa \\
\hline Industry of core business & Specialist foundation engineering & $\begin{array}{l}\text { Mining, exploration and geo } \\
\text { surveying }\end{array}$ & $\begin{array}{l}\text { Tea-packing (Teekanne GmbH } \\
\& \text { Co. KG) }\end{array}$ & Tunnel construction, pipe jacking \\
\hline User innovation business & Construction machines & $\begin{array}{l}\text { Measuring systems for } \\
\text { exploration }\end{array}$ & Tea-packing machines & Pipe jacking machines \\
\hline Revenues (in EUR Mio.) $^{1}$ & 1,278 & 106 & 385 & 15.3 \\
\hline Employees $^{1}$ & 8.872 & 611 & 1,500 & ca. 65 \\
\hline Patents granted $^{2}$ & 316 (years 1961-2011) & 257 (years 1927-2011) & 205 (years 1913-2011) & 0 \\
\hline $\begin{array}{l}\text { Amount of interviews } \\
\text { conducted }\end{array}$ & 5 & 2 & 3 & 1 \\
\hline \multirow{6}{*}{ Archival data used } & Annual reports & Annual reports & Product catalogues & Customer magazines \\
\hline & Customer magazines & Product catalogues & Book about firm history & Product catalogues \\
\hline & Product catalogues & Press articles & Press articles & Press articles \\
\hline & Book about firm history & Academic literature & Academic literature & Academic literature \\
\hline & Press articles & & & \\
\hline & Academic literature & & & \\
\hline $\begin{array}{l}\text { Interviews with industry or } \\
\text { academic experts }\end{array}$ & yes & yes & no & yes \\
\hline
\end{tabular}

\section{Table 1: Overview of cases}

Notes:

${ }^{1}$ The firm's revenues and number of employees refer to the year 2009.

${ }^{2}$ Germany

Sources: Bauer AG (2010), Creditreform (2010), DMT GmbH \& Co KG (2011), Teekanne GmbH \& Co KG (2007).

Internet: http://www.bauer.de; http://www.dmt.de/; http://www.max-boegl.de; http://www.teekanne.com; http://www.teepack.com; http://www.tunnelvortrieb.de (all accessed April 26, 2014); http://www.tuev-nord.de/en/DMT_5570.htm (accessed March 6, 2012) 


\begin{tabular}{|c|c|c|c|c|c|}
\hline \multicolumn{6}{|c|}{ Interviews with executives of case firms } \\
\hline Interview & Interviewed person & Position of interviewed person & Date & Duration & Interview documentation \\
\hline 1 & Prof. Thomas Bauer & CEO of Bauer AG & Dec 2007 & $1: 40 \mathrm{~h}$ & Complete Transcription \\
\hline 2 & \multirow{3}{*}{ Erwin Stötzer } & \multirow{3}{*}{ Managing director of Bauer Maschinen GmbH (retired) } & Jan 08 & $2: 00 \mathrm{~h}$ & Complete Transcription \\
\hline 3 & & & Feb 08 & $0: 30 \mathrm{~h}$ & Written notes \\
\hline 4 & & & Apr 08 & $1: 40 \mathrm{~h}$ & Complete Transcription \\
\hline 5 & Prof. Thomas Bauer & CEO of Bauer AG & Mar 2010 & $2: 00 \mathrm{~h}$ & Written notes \\
\hline 6 & Hans Loser & Member of the management board of WÜWA Bau GmbH \& Co. KG & Nov 10 & $1: 30 \mathrm{~h}$ & Complete Transcription \\
\hline 7 & Kurt Rippl & CEO of WÜWA Bau GmbH \& Co. KG & Aug 08 & $0: 10 \mathrm{~h}$ & Complete Transcription \\
\hline 8 & Dr. Stefan Lambertz & Member of the management board of Teepack Spezialmaschinen GmbH \& Co. KG & Feb 11 & $0: 55 \mathrm{~h}$ & Complete Transcription \\
\hline 9 & \multirow{2}{*}{ Wilhelm Lohrey } & \multirow{2}{*}{ Technical Director of Teepack Spezialma-schinen GmbH \& Co. KG (retired) } & Feb 11 & $0: 50 \mathrm{~h}$ & Complete Transcription \\
\hline 10 & & & Mar 2011 & $0: 30 \mathrm{~h}$ & Complete Transcription \\
\hline 11 & \multirow{2}{*}{ Dr. Bodo Lehmann } & \multirow{2}{*}{ Head of the Exploration \& Geosurvey Division of DMT GmbH \& Co. KG } & Feb 11 & $0: 50 \mathrm{~h}$ & Complete Transcription \\
\hline 12 & & & Apr 11 & $0: 10 \mathrm{~h}$ & Complete Transcription \\
\hline
\end{tabular}

Table 2: List of primary interviews

\begin{tabular}{|c|c|c|c|c|c|}
\hline \multirow{2}{*}{\multicolumn{2}{|c|}{$\begin{array}{l}\text { Interview Intervie wed person } \\
\text { Interviews with academic experts }\end{array}$}} & \multirow[t]{2}{*}{ Position of interviewed person } & \multirow[t]{2}{*}{ Date } & \multicolumn{2}{|c|}{ Duration Interview documentation } \\
\hline & & & & & \\
\hline 1 & Dr. Frank Ksienzyk & \multirow{3}{*}{ Researchers at Technische Universität Bergakademie Freiberg } & Feb 08 & $0: 30 \mathrm{~h}$ & written notes \\
\hline 2 & Prof. Dr. Matthias Reich & & Feb 08 & $0: 10 \mathrm{~h}$ & written notes \\
\hline 3 & Chris Reinhold & & Feb 08 & $0: 05 \mathrm{~h}$ & written notes \\
\hline 4 & Prof. Dr. Jürgen Grabe & Professor at Technische Universität Hamburg-Harburg & Feb 08 & $0: 15 \mathrm{~h}$ & written notes \\
\hline 5 & Jörg Gutwald & Researcher at Technische Universität Darmstadt & Mar 2008 & $0: 15 \mathrm{~h}$ & written notes \\
\hline 6 & Ercan Tasan & Researcher at Technische Universität Berlin & Mar 2008 & $0: 03 \mathrm{~h}$ & written notes \\
\hline \multicolumn{6}{|c|}{ Interviews with industry experts } \\
\hline 1 & Dr. Karlheinz Bauer & Member of the supervisory board of Bauer AG, former CEO & Apr 08 & $0: 05 \mathrm{~h}$ & written notes \\
\hline 2 & NN & Employee at Züblin Spezialtiefbau GmbH & Mar 2008 & $0: 25 \mathrm{~h}$ & written notes \\
\hline 3 & Mr. Maierhoff & Employee at Franki Grundbau GmbH \& Co. KG & Mar 2008 & $0: 10 \mathrm{~h}$ & written notes \\
\hline 4 & Mr. Sedlmeyer & Employee at PST Grundbau GmbH & Feb/Mar 2008 & $0: 05 \mathrm{~h}$ & written notes \\
\hline 5 & Mr. Nolte & Owner and Managing Director of Nolte Grundbau GmbH & Feb/Mar 2008 & $0: 04 \mathrm{~h}$ & written notes \\
\hline 6 & Mr. Klar & Former CEO of H\&S Tee Gesellschaft & Sep 10 & $0: 55 \mathrm{~h}$ & complete transcription \\
\hline
\end{tabular}

Table 3: List of secondary interviews 


\section{Sample quote from intervieus}

'The feedback has to come from the construction site, and I also sometimes tell the mechanical engineers 'Drive to the construction site, talk', because the machine operators are most important guys, naturally, you have to discuss with them and they also can tell you relatively fast, where they think, that there is potential improvement." (Wüwa)

"Well, in the field of packaging single, little portions - not only in the tea area -, but also elsewhere, it was not yet common. That is to say, the type of packaging machine was real new." (Teekanne)

"It is obvious, our people simply built their own tools, and they knew how to use them, how to press their buttons, how to attach the cogs, and not only thought about it theoretically, but developed them in practice on the construction site." (Bauer)

"[We build the devices] for our own purpose - we said we wanted to explore the coal seams underground, and then we started building equipment for it." (DMT)

"[W]e also have expertise with respect to the complete tea processing process, [...]. I believe this is a big advantage in the reputation." (Teekanne)

Combined Codes

Needs are formulated by users within the

Needs cannot be adequately fulfilled

Problems are solved by maintenance an engineers

New products are developed in house

Awareness and legitimacy of the brand

[Those who buy from us], simply have to accept, that we also are in a competition with them. And who doesn't want to buy from a competitor, has to go to company ABC, but there Credibility among customers due to use

he doesn't have a partner, who has an understanding about the process, who can help him on the construction site, who develops his machines out of the operation. He has an Credibility among custorience original unit advantage that $\mathrm{ABC}$ simply is not a competitor, but he has the disadvantage that $\mathrm{ABC}$ understands way less about the business than we do." (Bauer)

"[The machine buyers] just had known [Teekanne] before the war and they also had the trust in them [...]" (Teekanne)

Existing business relationships to potential

customer

"So first we enabled the other firms to do the werk at all. Before, they couldn't do this. But we were contracted by the site manager, he said, I need 20 poles now, do it for me

Bauer. [After the purchase of equipment from Bauer], their own subsidiary could do that, so he didn't ask Bauer anymore." (Bauer)

"Selling your own machines doesn't seem particularly easy at first. Here in Germany, where our machine sales were very strong, the customers automatically were our man competitors. The construction department was naturally not too pleased about that". (Bauer)

"We have many projects where we meet regularly, where we try to optimize internal processes i.e. maintenance processes. [...]."(Teekanne)

Conflicts stimulated by cusstomer

Internal conflicts between original and new business unit

Conflicts between units, management easing tensions

Mechanisms to mitigate internal conflicts

"We built five machines each year for us, and were very successful with it and that was good that way, and the small equipment industry, which saw these successful machines here, of course picked up the ideas, reconstructed them, but then had the advantage of being able to sell the machines not only to one customer, but to 20 customers. And if you can sell to 20 customers, you can sell 30 pieces each year [...]. And this lead really fast to them having lower specific costs of development, that they are just more productive on the market than we are." (Bauer)

"If we start building machines and I have four mechanical engineers up here, where ten years ago there was only one, well they also have to be financed somehow." (WÜWA)

"We realized[...] that the market doesn't pay for you building equipment." (Bauer)

Cost cannot be allotted to end customers oft user business

"We try [in the area of special foundation construction] to find topics, that have different cycles, on the market. So when we were a special foundation construction company, then we Original business unit follows a cyclical are dependent on the overall construction market, if we drill wells, we are dependent on the demand for water in the world." (Bauer)

Origina

"By now, we are positioned so internationally, around the globe, in so many different topics, that I can tell you, that if the mechanical engineering drops a bit, I will still have growth in

construction. And that means, it doesn't hurt me on a group level. That means, I can play around with these two areas. [..] mechanical engineerung follows a different logic, as Business cycles run asynchronously construction." (Bauer)

"[...] there also were bad times for the company, and there always was one area that was doing better. [..] I can't scold the one, who is feeding me. And if machine construction is feeding me, I have to tolerate it." (Bauer)

\section{Table 4: Data structure}


A continuous stream of user innovations from the Needs which cannot be satisfied emerge in the Product development is based on discussions Ideas from the core business (Teekanne) are one Continuous stream of user knowledge helped to core business leads to the accumulation of deep construction unit and are taken up by the between service and product business unit. of three major sources of Teepack innovations. user-specific and solution knowledge, which in maintenance and mechanical engineers, who turn favors the move toward and the success of develop technology and machines to solve these user-manufacturer diversification through problems. supplying product innovation ideas and generating absorptive capacity for external user needs.

$2 \quad$ Good reputation based on the firm's original user Global awareness of the Bauer brand and strong Reputation is an important marketing factor, Reputation is an important selling argument that Own experiences from the construction business business increases credibility and legitimacy of the reputation as foundation engineering specialss especially in direct competition with companies the machines are used in the own tea-packing help to build trust and, therefore, are an important manufacturing business, and thus facilitates the supported entry into the market for machinery. that focus on selling instruments without services. business. move toward and the success of userselling argument. manufacturer diversification

3 User-manufacturer diversification entails inherent Conflicts emerge due to the fact that Bauer's Conflicts may come up when the own service unit Conflicts are more supplier-customer conflicts Existing conflicts are more supplier-customer conflicts between the user and manufacturer construction unit and the machinery unit's has a problem and the instrument unit prioritizes (e.g., related to machine quality). Discussion of conflicts than related to the user-manufacturer businesses, which hinders both the move toward customers are competitors. Conflicts are treated another customer. Conflicts are addressed and problems (more product-related than due to the duality. Management of conflicts often by the and the success of user-manufacturer as a given. They are openly discussed and resolved in meetings with the heads of the firm's duality) in meetings where also learnings CEO himself (as it is a rather small firm). Confficts diversification. $\quad$ mitigated under a common culture and umbrella respective units. from external customers (e.g., maintenance best are in general not related to the user-manufacturer duality.

4 Higher investments in user innovations entail a High development costs for superior machinery Especially at the beginning of the development, it Constanta was only built when a U.S. customer The steady growth from the repair shop toward a Higher investments in user innovations entail a High development costs for superior machinery Especially at the beginning of the development, it Constanta was only built when a U.S. customer The steady growth from the repair shop toward a
more urgent need to recoup the costs, both before could not be allocated to the construction business was necessary to spread the development costs (first buyer of Constanta, before Teekanne) paid real fullscale engineering department was financed more urgent need to recoup the costs, both before could not be allocated to the construction business was necessary to spread the development costs (first buyer of Constanta, before Teekanne) paid real fullscale engines
as well as after the establishment of a due to high cost pressure. Thus it made sense to over a large number of units to be able to finance in advance (difficult situation after WW II); still vie machinery sales. as well as after the establishment of a due to high cost pressure. Thus it made sense to over a large number of units to be able to finance in advance (difi
manufacturer unit. Higher investments thus favor spread investments costs across higher volumes of these development efforts. both the move toward and the success of user- machinery. manufacturer diversification. 5 If a firm's original user business and its new In the 1980, revenues from the machinery sector Relevant for DMT, as the firm diversifies risk by Flexibility of Teekanne-orders is more important Volume of machinery sales is too small to see this manufacturing business follow asynchronous subsidized the starving construction unit. The other serving rather different industries (i.e. oil, gas, than asynchronous economic cycles (Teekanne effect. However, having two main businesses does economic cycles, then market cyclicality favors way around, Bauer expect the construction unit to construction, geothermal energy). both the move toward and the success of user- support the machinery unit in case of econo depending on Teepack's utilization.

\section{Table 5: Support of propositions across cases}




\begin{tabular}{|c|c|c|c|}
\hline & $\begin{array}{l}\text { New product introduction by } \\
\text { manufacturing firm }\end{array}$ & User entrepreneurship and new firm creation & User-manufacturer diversification \\
\hline $\begin{array}{l}\text { Location of } \\
\text { knowledge for } \\
\text { user-driven } \\
\text { innovation }\end{array}$ & $\begin{array}{l}\text { Outside the organization, with } \\
\text { external users }\end{array}$ & $\begin{array}{l}\text { With a user who then becomes an entrepreneur; } \\
\text { potentially also with external users }\end{array}$ & Within the firm's user unit; potentially also with external users \\
\hline $\begin{array}{l}\text { Knowledge } \\
\text { transfer }\end{array}$ & $\begin{array}{l}\text { Crossing firm boundaries; high } \\
\text { transaction costs for establishing } \\
\text { contact and transferring need } \\
\text { knowledge; typically one-time } \\
\text { interaction }\end{array}$ & $\begin{array}{l}\text { Through creation of a new firm; mediated by the } \\
\text { person of the user-entrepreneur; one-time } \\
\text { interaction if user switches role to manufacturer; for } \\
\text { external user knowledge: low transaction cost due } \\
\text { to absorptive capacity for need knowledge }\end{array}$ & $\begin{array}{l}\text { Within the same firm; mediated by user-innovating individuals; } \\
\text { through establishment of a manufacturing unit; in steady state, by } \\
\text { crossing unit boundaries within the firm; low transaction cost; for } \\
\text { external user knowledge: low transaction cost due to absorptive } \\
\text { capacity for need knowledge }\end{array}$ \\
\hline $\begin{array}{l}\text { Synergies and } \\
\text { conflicts }\end{array}$ & $\begin{array}{l}\text { Synergies between the firm's } \\
\text { manufacturing and marketing } \\
\text { capabilities and external need } \\
\text { knowledge from users, though } \\
\text { limited due to organizational } \\
\text { separation }\end{array}$ & $\begin{array}{l}\text { Synergies between the entrepreneur's need } \\
\text { knowledge and the firm's manufacturing and } \\
\text { marketing capabilities, though transient if } \\
\text { entrepreneur switches roles for good }\end{array}$ & $\begin{array}{l}\text { Synergies between the two business units w.r.t. innovation based } \\
\text { on need knowledge, marketing, shared fixed cost, and revenue } \\
\text { smoothing; potential conflicts due to diverging goals of } \\
\text { manufacturer and user units }\end{array}$ \\
\hline $\begin{array}{l}\text { Complemen- } \\
\text { tary assets }\end{array}$ & $\begin{array}{l}\text { Technological knowledge; existing } \\
\text { organization and processes; financial } \\
\text { resources; manufacturing capacity; } \\
\text { distribution channels; brand; } \\
\text { legitimacy as a manufacturer }\end{array}$ & $\begin{array}{l}\text { Need knowledge; possibly access to user networks; } \\
\text { legitimacy as a user and shared identity with } \\
\text { customers (transient) }\end{array}$ & $\begin{array}{l}\text { Need knowledge; existing organization; financial resources; brand } \\
\text { spillovers from the original business; legitimacy as a user }\end{array}$ \\
\hline $\begin{array}{l}\text { Relationship } \\
\text { with } \\
\text { competing } \\
\text { manufacturers }\end{array}$ & $\begin{array}{l}\text { Competitors are well-known; } \\
\text { industry structure largely unaffected } \\
\text { by commercialization of user } \\
\text { innovation }\end{array}$ & $\begin{array}{l}\text { User entrepreneurship creates new competition to } \\
\text { incumbents; often, user entrepreneurs compete in } \\
\text { underserved niches or markets; typically small- } \\
\text { scale entry }\end{array}$ & $\begin{array}{l}\text { User-manufacturer diversification creates new competition to } \\
\text { incumbents; some incumbents are suppliers to the focal firm's } \\
\text { user unit; risk that incumbents imitate the focal user innovation }\end{array}$ \\
\hline $\begin{array}{l}\text { Relationship } \\
\text { with } \\
\text { customers and } \\
\text { users }\end{array}$ & $\begin{array}{l}\text { Customers well-known; customer } \\
\text { base largely unaffected by } \\
\text { commercialization of user } \\
\text { innovations }\end{array}$ & $\begin{array}{l}\text { Customers of the user entrepreneur are (former) } \\
\text { user peers }\end{array}$ & $\begin{array}{l}\text { Customers of the manufacturing unit are competitors of the user } \\
\text { unit }\end{array}$ \\
\hline
\end{tabular}

Table 6: Comparison of pathways to commercialization of user innovations 


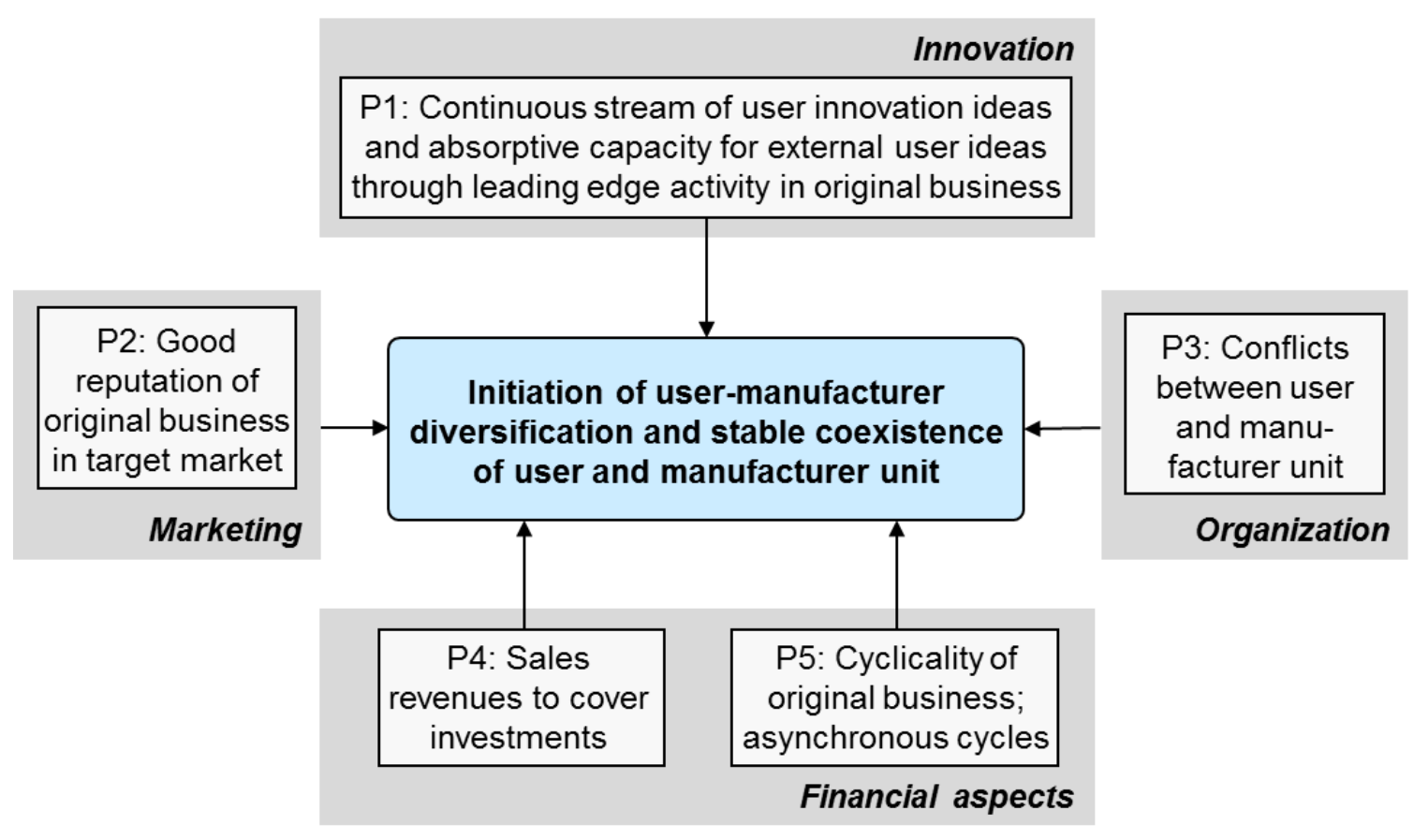

Figure 1: Framework of propositions 